This item was submitted to Loughborough's Research Repository by the author.

Items in Figshare are protected by copyright, with all rights reserved, unless otherwise indicated.

\title{
The new woman and decadent gender politics
}

\section{PLEASE CITE THE PUBLISHED VERSION}

https://www.cambridge.org/gb/academic/subjects/literature/english-literature-general-interest/decadenceliterary-history?format=HB\&isbn=9781108426299

\section{PUBLISHER}

Cambridge University Press

VERSION

AM (Accepted Manuscript)

\section{PUBLISHER STATEMENT}

This material has been published in revised form in Decadence: A Literary History edited by Alex Murray https://doi.org/10.1017/9781108640527. This version is free to view and download for private research and study only. Not for re-distribution or re-use. (C) The Author.

\section{LICENCE}

All Rights Reserved

\section{REPOSITORY RECORD}

Parker, Sarah. 2020. "The New Woman and Decadent Gender Politics". Loughborough University. https://hdl.handle.net/2134/12760196.v1. 


\section{The New Woman and Decadent Gender Politics Sarah Parker}

\section{Introduction}

The New Woman has a complex relationship with Decadence. For some critics, the Decadent movement is inherently misogynistic. In Daughters of Decadence (1993), Showalter argues that Decadence defines itself 'against the feminine and biological creativity of women. [...] In decadent writing, women are seen as bound to Nature and the material world because they are more physical than men, more body than spirit, they appear as objects of value only when they are aesthetised as corpses or phallicised as femme fatales. ${ }^{11}$ Decadent literature is intensely preoccupied with femininity, and yet simultaneously dismissive of women. Baudelaire, for example, claims that woman 'is a kind of idol, stupid perhaps, but dazzling and bewitching, who holds wills and destinies suspended on her glance'. ${ }^{2}$ This seductive power is only attained by 'lifting herself above Nature' using cosmetics. ${ }^{3}$ Thus, woman in her natural state remains inartistic and 'stupid'; her power comes from deceiving men.

Female sexuality is often depicted as threatening in Decadent literature. Huysmans' $A$ Rebours evinces a full-scale horror of the female body. Des Esseintes considers Moreau's Salomé 'the symbolic deity of indestructible lust, the goddess of immortal Hysteria'. ${ }^{4}$ His description of Salomé as 'a tall venereal flower' prefigures his later hallucination in which a 'deathly pale, nude woman' transforms into 'dark Amorphophall' that 'thrust their leaves into his abdomen'. ${ }^{5} \mathrm{He}$ castrates the penetrating plant ('experiencing a limitless disgust in seeing these warm, firm stems stirring in his hands') only for it to clasp him as a 'wild Nidularium which yawned, bleeding, in steel plates'. ${ }^{6}$ Des Esseintes is thus penetrated and consumed by a monstrous vagina, symbolic of woman and nature in diseased conspiracy.

In Wilde's The Picture of Dorian Gray, Sybil Vane is not so much monstrous as vapid and insignificant, dying off when Dorian ceases to love her. Henry Wotton's opinions of women reinforce Decadent tenets, as he explains to Dorian: 'My dear boy, no woman is a genius. Women are a decorative sex. They never have anything to say, but they say it charmingly. Women represent the triumph of matter over mind, just as men represent the triumph of mind over morals.' ' As Sally Ledger observes, in Dorian Gray femininity is 'accredited value as a "freefloating signifier" — as part of a pose, a performance_-which clearly belongs to the world of "art"; "woman," by contrast is represented in the novel as hopelessly corporeal, physical and leadenly material'. ${ }^{8}$ Femininity is thus 'loosened' from the body of woman, becoming associated 
with the artistic play of the male Decadent, whilst the undesirable qualities of nature are projected onto the female body, 'raw material' that needs to be shaped into art.'

However, the narrative I have sketched above is deliberately one-sided and leaves out much that united the Decadent writer with the New Woman. The two groups were explicitly connected in the mind of critics, reviewers and journalists during the 1890s. Commentators as diverse as Mrs. Oliphant, James Ashcroft Noble, and Max Nordau linked the Decadent and the New Woman through what they saw as their disproportionate interest in 'the sex question', considering this preoccupation a sign 'that English fiction has entered upon a stage of decadence'. ${ }^{10}$ Their shared rejection of marriage, fascination with social outcasts (the poor, criminals, prostitutes) and exploration of heightened experiences threatened to instigate anarchy in the minds of some critics. These tendencies were associated with French Decadence, which commentators such as Hugh E. M. Stutfield considered 'an exotic growth unsuited to British soil'.. ${ }^{11}$ He blames 'the popularity of debased and morbid literature, especially among women' for the increase in offensive realists such as George Moore and Grant Allen and neurotic "yellow" lady novelists' such as George Egerton. ${ }^{12}$ Female readerships were thus blamed alongside female (and female-focussed) authors.

These cultural anxieties reached their height during the Wilde trials of 1895. In a report on the trial, The Speaker claimed that: 'The new criticism, the new poetry, even the new woman, are all, more or less, the creatures of Mr Oscar Wilde's fancy.. ${ }^{13}$ Whilst this is clearly an exaggeration, Wilde did do much to promote the work of New Women, particularly through his editorship of The Woman's World (1887-1889). Eleanor Fitzsimons has revealed the extent to which he was intimately connected with a diverse group of women including actresses Ellen Terry and Sarah Bernhardt and writers such as Ada Leverson. ${ }^{14}$ Wilde is not a solitary example. As Talia Schaffer observes 'Male aesthetes and New Women were closely related-often quite literally so. ${ }^{15}$ Many of them shared the same publisher in the Bodley Head. John Lane's Keynotes Series, named after George Egerton's successful and scandal-provoking debut collection, included both New Women and Decadent authors. Within the pages of The Yellow Book, one can find works on New Woman themes by writers of both genders.

Nonetheless, this is not to suggest that all New Women writers participated in Decadence, or that they responded to Decadence in the same way. When Showalter writes that fin-de-siècle women writers needed to 'purge aestheticism and decadence of their misogyny and rewrite the myths of art that denigrated women,' she leaves the methods by which they might do so open. ${ }^{16}$ Some may do so by rejecting Decadence entirely, or by critiquing or parodying the male Decadent writer. Others may do so by writing Decadence themselves, transforming it from 
the inside. Joseph Bristow has recently written that the term female Decadence 'remains comparatively unused in modern literary histories of the 1890 s. $^{\prime}{ }^{17}$ This may be due to the enduring perception of Decadence as a male-centred movement, but is perhaps also due to the fact that women's participation in Decadence is difficult to categorise. As Ann Ardis has written elsewhere, ' $[\mathrm{g}]$ eneralizations about female aestheticism simply will not hold'.. ${ }^{18}$ The same is true of female Decadence. My aim in this chapter is to capture the complexities of New Women writers' engagements with Decadent tropes, themes and styles. These are mobilised in diverse ways across even a single author's oeuvre. For example, George Egerton and Kate Chopin use Decadent imagery to express the transgressive possibilities of female desire. Elsewhere, they use the same tropes to condemn the sexual excesses of men and to hint at the dangers of surrendering to pleasure. Such Decadent engagements are not confined to prose. I conclude by discussing Decadent poetry by Olive Custance, proposing that the Decadent mode offers the woman poet a way to write about various forms of desire (hetero- and homoerotic) without adhering to a fixed lyric position.

\section{George Egerton}

George Egerton (Mary Chavelita Dunne Bright) was a literary sensation of the 1890s. Her first collection of short stories Keynotes (1893) launched her career. John Lane named the most significant book series of the fin de siècle after her collection. The title page designed by Aubrey Beardsley was later issued in colour as a promotional poster for the series. Before one reads the first line of text, this image draws links between the umbrella-wielding New Woman to the left of the frame, and the Decadent Pierrots cavorting beneath. Egerton's frank depiction of female sexual desire and her psychological realism marked her writing as both part of, and a challenge to, the literature of Decadence. Her impressionistic short fiction reflects her immersion in diverse literary cultures; although born in Australia, Egerton spent significant periods of her life in Ireland, Germany, the United States and England. Tina O’Toole argues that Egerton's 'migrations [...] enabled her to develop highly unusual types of subjectivity in fiction. ${ }^{19}$ Egerton was particularly influenced by Scandinavian fiction; during her time in Norway in the late 1880s, she read the works of Henrik Ibsen, August Strindberg, Ola Hansson, and Knut Hamsun. She later translated Hamsun's novel, Hunger (1899) and Hansson's Young Ofeg's Ditties (1895); the latter heavily influenced by the philosophies of Frederich Nietzsche. Egerton is generally agreed to have been the first to reference Nietzsche in English. Allusions to his work run throughout 
Keynotes: for example, when Egerton use of the phrase 'ewig weibliche' (eternal feminine). ${ }^{20}$ Such associations intensified the negative reception Egerton's volume received. Following Nordau, Stutfield condemned Nietzsche's ideas as 'egomania,' mocking Egerton for following 'a German imbecile'. ${ }^{21} \mathrm{He}$ associates such 'neuropathic fiction' with sexual excess, complaining that: 'Emancipated woman, in particular loves to show her independence by dealing freely with the relations of the sexes'. ${ }^{22}$

Nietzschean influence and daring sexual freedom are established in the first story of Keynotes, 'A Cross Line.' The story concerns a married woman, Gypsy, who meets a young man whilst out fishing one day and embarks on an adulterous affair. The affair itself takes place elliptically between the episodes recounted in the narrative. The story is primarily concerned with Gypsy's inner world, for 'her busy brain, with all its capabilities choked by a thousand vagrant fancies, is always producing pictures and finding associations between the most unlikely objects'. ${ }^{23}$ The first lines find her dreaming of a 'little sketch [...] of a fountain scene in Tanagra' (3) - a reverie broken by the intruding man. Gypsy's fantasies culminate later in the story, resulting in its most Decadent scene. As she lies on her back watching the clouds, Gypsy imagines herself on the 'back of a swift steed [...] the swing under her of his rushing stride' (8). She then pictures herself on a stage in 'an ancient theatre':

with hundreds of faces upturned toward her. She is gauze-clad in a cobweb garment of wondrous tissue; her arms are clasped by jewelled snakes, and one with quivering diamond fangs coils round her hips [...] She can see herself with parted lips and panting, rounded breasts, and a dancing devil in each glowing eye, sway voluptuously to the wild music that rises, now slow, now fast, now deliriously wild, seductive, intoxicating, with a human note of passion in its strain. (9)

This scene is Decadent in both style and subject matter. The rhythmic listing of adjectives recalls both the privileging of sound over sense associated with Decadent poetics (particularly that of Swinburne) and the listing that features in famous Decadent novels such as $\grave{A}$ Rebours and The Picture of Dorian Gray. These lists obsessively detail the luxurious, often oriental, items collected by their Decadent anti-heroes. Gypsy here appears arrayed in such 'exotic' trappings. The scene also hints at the Decadent fascination with Ancient Greece; the 'answering' chorus of men recall the dithyrambic chorus sung in honour of Dionysus, with Gypsy as a maenadic worshipper. This episode also recalls the story of Salomé (Wilde's play was published in French in 1891, two years before Egerton's story). The tale of the capricious princess whose voracious desire results 
in the decapitation of John the Baptist epitomises the male Decadent's horror of castration at the hands of an alluring, heartless woman. However, drawing on the Decadent femme fatale, Egerton reimagines this myth: she uses Salomé to celebrate rather than condemn female sexuality. Gypsy's dancing climaxes with her own pleasure rather than man's destruction:

One quivering, gleaming, daring bound, and she stands with outstretched arms and passion-filled eyes, poised on one slender foot, asking a supreme note to finish her dream of motion; and the men rise to a man and answer her, and cheer, cheer till the echoes shout from the surrounding hills and tumble wildly down the crags. (9)

Although Gypsy imagines a male audience, this daydream is auto-erotic and self-sufficient. Ledger reads it as 'an aestheticized rendering of female masturbation,' as its escalating rhythms result in Gypsy's exhaustion ('her eyes have an inseeing look and she is tremulous with excitement') (9). ${ }^{24}$ Following this orgasmic moment, Gypsy wonders if other women have 'this thirst for excitement' before meditating on their 'eternal wildness' (9) which men will never comprehend.

However, the daring possibilities opened up by Egerton's story are swiftly foreclosed by its ending: Gypsy discovers she is pregnant, and ends her affair in favour of motherhood. The possibilities for desire invoked by the dancing episode are shut down, but the Decadent energy conjured by this interlude lingers. Several critics have noted the complexities of Egerton's feminism; she rejected the term 'New Woman' and opposed female suffrage, claiming she had 'no emancipation theory to propound, no equality idea to illumine'. ${ }^{25}$ Egerton's feminism was essentialist; she believed woman to be 'man's superior, by reason of her maternity'. ${ }^{26}$ Egerton's response to Decadence was also more complicated than her reputation as one of Lane's star authors might suggest. Whilst Stutfield clearly felt that she was a confirmed 'yellow' novelist determined to corrupt society alongside Wilde and his ilk, Egerton herself expressed ambivalence regarding Decadence, particularly in relation to gender roles. In her later epistolary work Rosa Amorosa: The Love-Letters of a Woman (1901), Egerton (or rather a semi-autobiographical version of herself) discusses sexual inversion, admitting the possibility that 'a male spirit may be accidentally held in a perfect female body' resulting in increased 'genius' in woman. However, she considers the inverted male 'disastrous [...] a species of intellectual eunuch — the male in him feminised and the female of no sex what-ever. The decadent proper rather belongs here. ${ }^{27}$ This suggests that Egerton viewed Decadence as a regrettable development, potentially resulting in male degeneration and sterility. 
In keeping with Egerton's ambivalence, whilst Decadent imagery is used to celebrate female sexuality in 'A Cross Line,' Egerton uses similar tropes in a later story, 'The Mandrake Venus' (Fantasias, 1898) in order to condemn prostitution and the sexual corruption of both genders. Egerton conveys her message through the allegory of effete males' enthrallment to a domineering, sexually-perverse goddess, implying that Decadence unmans men as much as it corrupts and exploits women. The story commences with a pilgrim travelling 'along the highway of the world'. ${ }^{28}$ He encounters a troupe of young men dancing recklessly towards a city: 'ghost lads with sandalled feet, flower crowned and hyacinthine locked, as well as the youths of the present day' (2). These youths recall the Hellenic ephebes celebrated in Uranian poetry; the term 'hyacinthine' recalls Hyacinthus, the young lover of Apollo. ${ }^{29}$ Whilst the men appear engaged in homoerotic dancing, they are bound on an apparently heterosexual mission: 'To pay homage to the World Harlot, the Mandrake Venus, the Arch-wife, the Ever-existing, who has been, is, and will be' (3). The pilgrim eventually encounters this evil goddess sitting on a throne of bones and coins, clad in almost every accoutrement of Decadence:

His eyes were held by the gigantic female, couchant amidst the changeful drapery. [...] A flexible serpent, the lamellae of virgin gold, a triumph of the goldsmith art, encircled her loins: so cunningly were the diamond eyes set in the jewelled head that they seemed quick with an evil lustre. She held an iron thyrsus entwined with fresh bindweed, and the blooms of the enchantress nightshade in her hand. The eyes of all those who had entered the hall were fixed upon her, and she held them with her basilisk gaze. (3)

The Venus, with her 'her voluptuous, leprous, white body' (4) brings to mind Swinburne's 'Faustine' in her ancient evil and lust for gold. The sense of sexual perversity is reinforced by the phallic serpent encircling her loins and the Dionysian 'iron thrysis' she holds erect. This interlayering of Decadent symbolism suggests various kinds of sexual—not only female prostitution but also homoerotic desire. The Mandrake Venus is both femme fatale and hermaphrodite. Whilst the specific suffering of prostitutes is foregrounded in 'The Mandrake Venus' - the story concludes with 'the cry of the maid as she is torn from innocence and womanhood to minister to the service of the great Harlot mother' (4-5) - the allegory also functions as a warning against the corruption of male and female sexuality through Decadence. The undercurrent of homoeroticism also suggests other forms of male sexual exploitation; the young men urge each other on to acts of depravity which remain mysterious and unspecified (much like Dorian Gray's sins) — they simply disappear behind a curtain and the pilgrim later 
emerges 'with eyes heavy with the pain of what he had seen' (4). Egerton's story may have been influenced by the Wilde trials, which exposed the secret underworld of homosexuality, including male prostitution in Alfred Taylor's 'heavily perfumed rooms'. The resulting 'reactionary cultural environment' had direct implications for Egerton's career-she had to revise her volume Symphonies in line with the Bodley Head's new policies. ${ }^{30}$ Although it is difficult to ascertain Egerton's attitude to homosexuality, 'The Mandrake Venus' and her comments regarding the male Decadent suggest that she condemned male sexual dissidence along with female prostitution, using Decadent imagery to symbolise these twin evils. Therefore, whilst Decadent tropes are used in 'A Cross Line' to represent the freedom and wildness of female sexuality, in 'The Mandrake Venus' the very same tropes are utilised to represent corruption, exploitation and disease. For example, Gypsy dances with a serpent with 'diamond fangs coils round her hips'the same accessory as the Venus. This shows how the same Decadent images can be mobilised to strikingly different ends across an author's works. This makes it difficult to position Egerton's attitude to Decadence; her response is ambivalent and shifts across her oeuvre. She is both within and outside Decadence, contributing to Decadent literature whilst critiquing it through the very same imagery.

\section{Kate Chopin}

On the other side of the Atlantic, Kate Chopin was developing her own experimental Decadent prose. Set in New Orleans and the Louisiana Gulf Coast, her novel The Awakening (1899), along with a number of her short stories, uses a naturalist mode to explore the conflict between social expectation and self-determination, while drawing on various Decadent motifs. Chopin developed her literary style through reading French naturalists such as Guy de Maupassant and Émile Zola. In her essay 'Confidences', she describes her initial reactions to encountering Maupassant:

Here was a man who had escaped from tradition and authority, who had entered into himself and looked out upon life through his own being and with his own eyes; and who, in a direct and simple way, told us what he saw. When a man does this, he gives us the best that he can $[\ldots]$ He gives us his impressions. ${ }^{31}$ 
Maupassant's naturalism offered Chopin a new mode of expression; she valued his 'skillful rendering of subjective experience and his emphasis on the importance of individual consciousness'. ${ }^{32}$ Chopin's distinctive naturalistic Decadence was further developed through translating Maupassant's short stories. Between 1894 and 1898, she translated eight stories, instigating her own literary experimentation. One of the most recognisably Decadent stories is Maupassant's 'Un cas de divorce' (1886), translated by Chopin as 'A Divorce Case' in July 1894. In this story, a man rejects his young wife, preferring to indulge himself erotically with exotic flowers, particularly orchids: 'I love flowers; not as flowers, but as delicious and material beings. I pass my days and nights in the hot houses where I hide them as women are hidden in harems. ${ }^{33}$

Naturalism and Decadence in a man's writing were scandalous enough, but to utilise such literary aesthetics to render a woman's experience and inner life was a strikingly feminist act. In developing naturalistic techniques within her own writing, Chopin found a way to fearlessly explore female psychology, culminating in her most famous work, The Awakening (1899). The isolation and despair experienced by Chopin's unhappily married heroine Edna Pontellier echoes the Maupassant stories she translated, such as 'Solitude' and 'Suicide'. But the novel displays other Decadent literary influences. These emerge when Edna hosts a dinner party, the night before leaving her husband's home. At a table appropriately covered with 'yellow satin' with candles under 'yellow silk shades,' Edna presides in a yellow gown. This backdrop forges a connection between the New Woman's bid for freedom and the trappings of Decadent sensuality, setting the scene for the novel's most Decadent episode. After the feast, a guest playfully garlands Victor LeBrun (the brother of Robert, Edna's lover) with roses:

As if a magician's wand had touched him, the garland of roses transformed him into a vision of Oriental beauty. His cheeks were the color of crushed grapes, and his dusky eyes glowed with a languishing fire. [...]

'Oh! to be able to paint in color rather than in words!' exclaimed Miss Mayblunt, losing herself in a rhapsodic dream as she looked at him.

"There was a graven image of Desire

Painted with red blood on a ground of gold.",

murmured Gouvernail, under his breath. ${ }^{34}$

In performing this momentary tableau vivant, the usually buoyant Victor transforms into a symbolic, Dionysian figure. ${ }^{35}$ These associations are reinforced by the evocation of the opening 
lines from Algernon Charles Swinburne’s ‘A Cameo' (Poems and Ballads, 1866); Swinburne’s sonnet imagines Desire as flanked by Pleasure and Pain on either side, followed by Hate and Death: 'And the strange loves that suck the breasts of Hate / Till lips and teeth bite in their sharp indenture..${ }^{36}$ Victor thus functions as a warning to Edna, hinting at the pain to come when her lover Robert eventually abandons her. Breaking his trance, he sings the refrain previously sung by Robert: 'Ah! si tu savais!' ('Ifyou only knew', 100). Victor becomes an uncanny avatar of Robert, mocking Edna with her own unrequited desire. Edna begs him to stop, spilling her wine and eventually flinging the garland across the room. Ann Heilmann reads this scene as reflecting the vexed relations between the New Woman and the Decadent: 'The garlanded gauntlet flung across the room signals the end of the potential coalition between New Woman and decadent man. ${ }^{37}$ However, reviewers regarded Chopin as in league with Decadent writers, rather than rejecting Decadence. One described The Awakening as written with 'a bald realism that fairly out Zolas Zola,' fearing that the novel 'will fall into the hands of youth, [...] promoting unholy imaginations and unclean desires'. ${ }^{38}$ Another compared it to 'Aubrey Beardsley's hideous but haunting pictures with their disfiguring leer of sensuality.. ${ }^{39}$ Indeed, Chopin herself viewed her work as continuity with Decadence, rather than opposed to it. She subscribed to The Yellow Book and The Chap-Book, submitting stories to both journals. The Chap-Book (1894-1898) was in many ways an American counterpart to The Yellow Book. Chopin wrote to the publishers: 'I would greatly like to see one of them—some of them—something — anything-over my name in the Chap-Book.. ${ }^{40}$ They declined her submissions, including 'An Egyptian Cigarette,' which was eventually published in Vogue (19 April 1900).

Chopin's much-anthologised story would surely have been suitable material for the journal. As Ledger observes, ‘the "exoticism” of Chopin's narrative fragment is distinctly suggestive of decadence. ${ }^{41}$ This exoticism is established by the opening lines of the story:

My friend, the Architect, who is something of a traveller, was showing us various curios which he had gathered during a visit to the Orient. 'Here is something for you' he said, picking up a small box and turning it over in his hand. 'You are a cigarette-smoker; take this home with you. It was given to me in Cairo by a species of fakir, who fancied I had done him a good turn.'

The box was covered with glazed, yellow paper, so skilfully gummed as to appear to be all one piece. It bore no label, no stamp-nothing to indicate its contents. ${ }^{42}$ 
If we were in any doubt of the Decadent reverie to come, the 'glazed, yellow paper' anticipates it, reinforced by wrappers 'of pale-yellow paper' and tobacco 'almost the same colour' (1). Alongside this over-determined yellowness, the opening scenario confirms the narrator is a modern woman, set apart from others of her kind. She proposes to try the cigarette 'after the coffee, if you will permit me to slip into your smoking-den. Some of the women here detest the odour of cigarettes' (2). By slipping into the smoking-den, the narrator infiltrates the maledominated space more usually occupied by the Decadent (anti-)heroes. Its furnishings (including a divan) are 'exclusively oriental' (2). As she reclines, the speaker commends herself for 'having escaped for a while the incessant chatter of the women that reached me faintly' (2)-reiterating the misogynist Decadent view of women as earth-bound, trivial creatures.

However, on taking 'one long inspiration of the Egyptian cigarette' she is immediately transported to a hostile landscape, a barren desert, where she lies in agony. The woman's lover has abandoned her, and she haunted by memories of sensual pleasure: 'I turned from the gods and said: "There is but one; Bardja is my god." That was when I decked myself with lilies and wove flowers into a garland and held him close in the frail, sweet fetters' (3). In contrast to her current arid environment, the woman's reminiscences conjure a world of pseudo-oriental pleasures: 'There is music in the Temple. And here is fruit to taste. Bardja came with the music - The moon shines and the breeze is soft-A garland of flowers-let us go into the King's garden and look at the blue lily, Bardja' (4). Thus, the story functions as erotic fantasy, enclosed within a hallucinatory episode, in a similar manner to Gypsy's daydream. Schaffer argues that such 'fantasias' permitted female aesthetes to write about otherwise taboo topics, by situating 'a woman's desires in the unreal space of “dream"”. ${ }^{43}$ Chopin's narrative certainly fits such a definition; Bardja's name and references to camels, oracles and temples, all contribute to an unspecified, pseudo-Egyptian setting.

However, this fantasy is ultimately a masochistic one, concluding in agony and selfabasement, as the speaker drags herself after her lover, eventually collapsing in the sand. The episode culminates in suicide: 'Despair is bitter and it nourishes resolve. I hear the wings of a bird flapping above my head, flying low, in circles. [...] The river is near at hand' (3-4). This ending echoes that of The Awakening, which Chopin began two months after writing 'An Egyptian Cigarette'. Like a participant emerging from past-life regression, the narrator's death precipitates her awakening. Visibly shaken, she rejects the future visions potentially offered by the hallucinogenic cigarettes: 
As I looked at the cigarettes in their pale wrappers, I wondered what other visions they might hold for me; what might I not find in their mystic fumes? [...]

I took the cigarettes and crumpled them between my hands. I walked to the window and spread my palms wide. The light breeze caught up the golden threads and bore them writhing and dancing far out among the maple leaves. (4)

The architect returns and notices her pallor; she explains that she is 'A little the worse for a dream' (5). How to interpret this ending? As with Egerton's 'A Cross Line,' the story seems to conclude by rejecting desire and fantasy. We may read the protagonist as being chastened for her presumption that she is different from other women by being forced to inhabit a vision of (willing) female abasement. Does this mean that women should reject such Decadent pleasures; that Egyptian cigarettes are to be smoked by men only? Once again, Decadent visions carry both pleasurable possibilities and a warning. Mary E. Papke argues that, along with marriage, Chopin viewed 'the purely sexual as another trap into which both men and women fall'. ${ }^{44}$ Unlike Edna Pontellier, the narrator of 'An Egyptian Cigarette' survives desire and returns to her easy friendship with the architect. The implication could be that until men and women have reached true equality, sexual desire will remain a destructive force. But Chopin herself, as Papke notes, did not deny her own visions. ${ }^{45}$ By articulating the dream in the first place, Chopin invokes the radical potentialities of female fantasy, leaving the scent lingering in the air like smoke.

\section{Olive Custance}

Decadent women's writing is of course not confined to prose; women writers also contributed to Decadence in poetry. Alongside other fin-de-siècle poets, such as Graham R. Tomson (later Rosamund Marriott Watson), Michael Field (Katharine Bradley and Edith Cooper) and Sarojini Naidu, Olive Custance emerges as one of the most prominent Decadent women poets of the era, publishing frequently in The Yellow Book. Richard Le Gallienne declared that her debut volume Opals (1897) 'contains the best poetry written by a woman for quite a long time'. ${ }^{46}$ This volume is bejewelled with Decadent symbolism—from the feverish kisses of 'Doubts', compared to 'the wine of pain, / Fate's purple wine, so fiery sweet!' to the 'mauve-silver twilight' of 'Statues' in which the speaker imagines pressing 'warm lips against your cold white mouth!" ${ }^{47}$ The most intensely Decadent poem, 'The Music of Dvorák', concludes the volume. We are again in the realm of the female dancer — or rather dancers, as Custance envisions a troupe of ecstatic dancing girls: 
Beneath a golden dome, an emerald floor,

Crowded with dancing girls ... the flash of feet,

The flutter of loose robes, the rhythmic beat

Of drums ... The singing of sad violins,

The clash of cymbals ... So the music wins

To fullest melody ... and through it rings

The silver clank of anklets and the sweet

Tinkling sound of little shaken bells! (73)

Aspiring to the Paterian 'condition of music', the poem aims at a blending of the arts typical of aestheticism. The insistent rhyming couplets, fluid enjambment, and Custance's characteristic use of ellipses conjure the shifting tempos of the dance. Though the Czech composer Antonín Leopold Dvořák may seem an unlikely choice (compared to say Wagner), his lively folk rhythms, such as the Slavonic Dances (composed in 1878 and 1886), are here imagined as unlocking the 'eternal wildness' in woman. In contrast to Gypsy's solitary performance, this group of women dance together, becoming increasingly frenzied and maenadic: 'Lightly each coryphée her sister swings, / Mad with the mystic measure of the dance' (73). The music builds in intensity, resulting in a climax:

Then suddenly they pause, as if by chance,

Motionless . . . as the flutes and viols are stilled.

Each slender sinuous body, spell bound, thrilled

With triumph in its last, most perfect pose ...

Each lovely head thrown back, as in a trance

Immovable they stand in glittering rows. (73-4)

This tableau enables the speaker to freely admire the women's 'sinuous' forms. In language strikingly close to 'A Cross Line', Custance imagines a collective erotic moment; each woman's head is 'thrown back', poised in a moment of intense pleasure. Rather than a male audience, Custance's poem captures the effect of this performance on a single viewer, the speaker herself. In a coda, she ponders whether this experience was a dream:

Silence and darkness! ... was it then a dream? 
Entangled in a passionate mystery $[\ldots]$

... So weary souls drift vision-ward, and see,

Looking between the heavy lids of sleep,

Reflections of themselves as they might be! (73-4)

Custance's poem sits comfortably alongside those of male Decadent poets, such as John Barlas and Arthur Symons. In Barlas's 'The Dancing Girl', 'a damsel tinkling / With a timbrel' dances with her shadow on a painted screen, until the speaker's 'dizzy brain, betwixt them, spinning / Wondered which was true', echoing the disorientation at the end of Custance's poem. ${ }^{48}$ In 'To a Dancer' Symons' speaker expresses possessive desire for the dancer, leading to the delusion that she is dancing just for him: 'Her body's melody, / [...] Thrills to the sense of all around, / Yet thrills alone for me!' ${ }^{49}$ Although some may argue that this epitomises the objectifying male gaze, Symons's work shows that subject/object binaries may potentially be undone via Decadent aesthetics. His poems often identify with the dancer, to the point where the distinction between viewer/viewed collapses:

My life is like a music-hall,

Where, in the impotence of rage,

Chained by enchantment to my stall,

I see myself upon the stage

Dance to amuse a music-hall. ${ }^{50}$

These moments of slippage between subject/object, viewer/viewed, challenge an overly simplistic reading of such poems as maintaining binary distinctions between male and female, audience and performer. The same is true of Custance's 'The Music of Dvorák'. Through writing of her complex desire for and identification with the dancer, Custance expresses both homoerotic desire for the female dancer's body and a longing to experience the pleasure of dancing herself. The dancer is both admired from afar and an intrinsic part of the self. Through occupying the conventional Decadent male position of audience member, Custance transforms that position into an affirmation of female desire and freedom.

'The Music of Dvorák' is one of several poems about female dancers written by Custance. In her second volume Rainbows (1902), Custance praises 'A Dancing Girl' in exoticising terms: 'Dark daughter of a dancing race / How do you weave your mystic spells?' (34). Once again, dancing, orientalism and fantasy combine to convey (a problematic) female 
eroticism. In 'The White Witch', Custance eulogises Natalie Barney, with whom she enjoyed a brief affair, as both a dancing femme fatale and an androgyne, incorporating images from Pater and Swinburne. As I have argued elsewhere, the ambiguity of lyric, in which the speaker and addressee are often left unmarked by gender, enables Custance to express desire without adhering to a fixed position. For example, in 'Antinous', the ungendered speaker praises both the male statue of the title and a female companion, declaring: 'I spoke of you, Antinous, with her who is my heart's delight' (50). Such poems layer male homoerotic, lesbian and heterosexual desires, blurring distinctions not only of gender and sexuality, but also between living subjects and motionless objects. In Custance's poetry, desire has the potential to bring objects to life and to fix living things into art (as with the frozen tableau of dancing girls).

Some literary historians sketch a narrative in which possibilities for sexual dissidence were precluded following the Wilde trials, particularly within The Yellow Book. However, Linda K. Hughes has argued that in fact 'women's poetry helped sustain the presence of Decadent verse in the journal in the aftermath of the Wilde trial, especially Decadent exploration of perverse sexuality..${ }^{51}$ Custance was the most significant contributor in this sense- of her eight poems in Lane's journal, six were published after the Wilde trial. Custance's engagement with Decadence continued into the twentieth century. For example, her poem 'Hyacinthus', published in The Blue Bird (1905) praises the martyred youth accidentally murdered by his lover Apollo, whilst 'Peacocks: A Mood' expresses sympathy for 'my gay youth' that: 'Tempts with its beauty that disastrous day'. ${ }^{52}$ In such poems, Custance expresses both sympathy and identification with the doomed homosexual aesthete-making it all the more surprising that such works were published in the supposedly reactionary Edwardian era.

For poets like Custance, Decadence opens up multiple possibilities for identification and desire. The woman poet does not simply imagine herself in the position of the male Decadent, occupying the male gaze; she transforms that position from the inside, raising the possibility of a female gaze that is actively desiring and that encompasses shifting identificatory positions. While this dissolution of boundaries between subject/object may provoke a sense of chaos and anxiety for male Decadent writers (for example, Des Esseintes's nightmare of being simultaneously penetrated and enclosed by the monstrous flower), it invokes thrilling possibilities for female Decadent writers. Decadent aesthetics ultimately break down the subject-object binary altogether, forging new possibilities for subjectivity and sexuality.

\section{Conclusion}


Despite claims of misogyny, this chapter has shown that women writers found in Decadence ways to utilise and transform Decadent imagery towards their own ends. Such skilful manipulations of stock Decadent symbolism (such as the exotic female dancer) demonstrate that women did have to reject Decadence entirely but rather remake it in their own image. In the process, they both contributed to and re-defined Decadent literature. However, I have also shown that such tropes did not entirely shed their connotations of sexual danger, corruption or depravity. Decadence still held potentially destructive associations for women, and could be used as a warning as well as an invitation to fantasy.

To return to the issues of categorisation with which I began this essay, how useful are the terms 'female Decadent', 'female aesthete' and 'New Woman' writer when assessing this work? Are these terms mutually exclusive or can we bring them into dialogue? I propose that it is more helpful to think in terms of individual works rather than writers. Rather than a static posture, Decadence is more often a mode and aesthetic adopted within a wider oeuvre which may encompass a variety of other positions_-such as those of female aestheticism or New Woman polemic (and more besides). Decadent male writers create works that are not consistently and unambiguously Decadent, and yet we still discuss them under the category of Decadence where relevant. By expecting women writers to be consistently Decadent and, moreover, to be Decadent in ways primarily associated with male-orientated literary tradition, we have overlooked the important role they play within the movement. Indeed, as recently suggested at the concluding roundtable of the 'Women Writing Decadence' conference, including women writers in discussions of Decadence entails much more than 'slotting' them into accepted categories; the understanding of Decadence itself will be redefined through considering women's distinctive contributions.

\section{NOTES}

${ }^{1}$ Elaine Showalter, 'Introduction', Daughters of Decadence: Women Writers of the Fin-de-Siècle, ed. Elaine Showalter (London: Virago, 1993), x.

${ }^{2}$ Charles Baudelaire, 'Woman' in The Painter of Modern Life, trans. Jonathan Mayne (London: Phaidon Press, 1964), 30. 
${ }^{3}$ Baudelaire, 'In Praise of Cosmetics' in Painter, 33.

${ }^{4}$ Joris-Karl Huysmans, Against the Grain, trans. John Howard (New York: Lieber \& Lewis, 1922), 95.

${ }^{5}$ Huysmans, Against, 99; 149; 150.

${ }^{6}$ Huysmans, Against, 150.

${ }^{7}$ Oscar Wilde, The Picture of Dorian Gray, ed. Joseph Bristow (Oxford: Oxford University Press, 2006), 42.

${ }^{8}$ Sally Ledger, The New Woman: Fiction and Feminism at the Fin de Siècle [citing Rita Felski, 'The

Counterdiscourse of the Feminine in Three Texts by Wilde, Huysmans, and Sacher-Masoch', PMLA, 106.5 (1991), 1099], 108.

${ }^{9}$ Rita Felski, The Gender of Modernity (Cambridge: Harvard UP, 1995), 91.

${ }^{10}$ Thomas Bradfield, 'A Dominant Note of some Recent Fiction,' Westminster Review, 142 (1894), 543.

${ }^{11}$ Hugh E. M. Stutfield, 'Tommyrotics,' Blackwood's Edinburgh Magazine (June 1895), 834.

${ }^{12}$ Stutfield, 'Tommyrotics,' 834; 833.

13 “New" Art at the Old Bailey', The Speaker, 13 April 1895, 403.

${ }^{14}$ Eleanor Fitzsimons, Wilde's Women: How Oscar Wilde Was Shaped by the Women He Knew

(London: Duckworth Overlook, 2015).

${ }^{15}$ Talia Schaffer, The Forgotten Female Aesthetes: Literary Culture in Late-Victorian England

(Charlottesville: University of Virginia Press, 2000), 21.

${ }^{16}$ Showalter, Daughters, x-xi.

${ }^{17}$ Joseph Bristow, 'Female Decadence', The History of British Women's Writing, 1880-1920, ed. Holly A. Laird (Basingstoke: Palgrave Macmillan, 2016), 94.

${ }^{18}$ Ann Ardis, 'Netta Syrett's Aestheticization of Everyday Life,' Women and British Aestheticism, eds. Talia Schaffer and Kathy Psomiades (Virginia: Virginia UP, 1999), 244.

19 Tina O’Toole, 'George Egerton's Translocational Subjects' Modernism/modernity, 21.3 (2014), 827.

${ }^{20}$ From Nietzsche’s Beyond Good and Evil (1886); see Daniel Brown, ‘George Egerton’s Keynotes: Nietzschean Feminism and Fin-de-Siecle Fetishism' Victorian Literature and Culture 39 (2011), 150.

${ }^{21}$ Stutfield, 'Tommyrotics', 838.

${ }^{22}$ Stutfield, 'Tommyrotics', 836.

${ }^{23}$ George Egerton 'A Cross Line' in Keynotes and Discords, ed. Sally Ledger (London: Continuum, 2006), 3. Subsequent page numbers in text.

${ }^{24}$ Ledger, 'Introduction', Keynotes and Discords, xxiii. 
${ }^{25}$ George Egerton, Letter to Ernst Foerster, 1 July 1900, quoted in Ann Heilmann, ed. The LateVictorian Marriage Question: A Collection of Key New Woman Texts: Volume 5 (New York: Routledge, 1998) 53-54.

${ }^{26}$ Egerton, Letter to Ernst Foerster, 54.

${ }^{27}$ George Egerton, Rosa Amorosa: The Love-Letters of a Woman (London: Grant Richards, 1901), 83-84.

${ }^{28}$ George Egerton, 'The Mandrake Venus' in Dreams, Visions and Realities, ed. Stephanie Forward (Birmingham: University of Birmingham Press, 2003), 1. Subsequent page numbers in text.

${ }^{29}$ Wilde's hair was described as: 'hyacinthine locks' during his trial (Evening News, 3 April 1895).

${ }^{30}$ Egerton complained to Lane in 1896: 'You did not say you wished a "milk and water" book on entirely different lines to that which made the success of Keynotes [...] I have had to change a great deal, out of concession to the new Bodley Head policy' (qtd. in Ledger, 'Introduction', xixii).

${ }^{31}$ Kate Chopin, 'Confidences' in Per Seyersted, ed. Complete Works of Kate Chopin, Volume II (Baton Rouge: Louisiana State University Press, 1969), 701).

${ }^{32}$ Wendy Martin, 'Introduction', New Essays on The Awakening, ed. Wendy Martin (Cambridge: Cambridge UP, 1988), 4.

${ }^{33}$ Chopin, 'A Divorce Case' in The Kate Chopin Companion: With Chopin's Translations from French Fiction, ed. Thomas Bonner (New York: Greenwood Press, 1988), 181.

${ }^{34}$ Kate Chopin, The Awakening, in The Awakening and Other Stories, Ed. Pamela Knights (Oxford: Oxford University Press, 2008), 99.

${ }^{35}$ Pamela Knights notes that the tableau may be inspired by Caravaggio's Bacchus (ca. 1595), (editorial notes to The Awakening and Other Stories, 372).

${ }^{36}$ Algernon Charles Swinburne, 'A Cameo', Poems and Ballads (London: J. C. Hotten, 1866), 130.

${ }^{37}$ Ann Heilmann, 'The Awakening and New Woman fiction,' in Cambridge Companion to Kate Chopin, ed. Janet Beer (Cambridge: Cambridge UP, 2008), 96.

38 'Books of the Week,' Providence Sunday Journal (4 June 1899), 58.

39 'Fresh Literature,' Los Angeles Sunday Times (25 June 1899), no page.

${ }^{40}$ Qtd. Toth, Kate Chopin, 296.

${ }^{41}$ Ledger, The New Woman, 97-99.

${ }^{42}$ Kate Chopin, 'An Egyptian Cigarette' in Daughters of Decadence, ed. Showalter, 1. Subsequent page numbers in text. Chopin foreshadows 'An Egyptian Cigarette' in her essay 'Confidences' (drafted eight months before, in September 1896) in which she plans to disguise 'myself as a gentleman smoking cigars with my feet on the table' (700). 
${ }^{43}$ Schaffer, Female Aesthetes, 50-51.

${ }^{44}$ Mary E. Papke, 'Kate Chopin’s Social Fiction' in Kate Chopin, ed. Harold Bloom (New York: Infobase Publishing, 2007), 56.

${ }^{45}$ Papke, 'Social Fiction', 58.

${ }^{46}$ Richard Le Gallienne, Sleeping Beauty and Other Prose Fancies (London: The Bodley Head, 1900), 161.

${ }^{47}$ Olive Custance, Opals, with Rainbows (New York: Woodstock Books, 1996), 53; 67. Subsequent page numbers in text.

${ }^{48}$ John Barlas, 'The Dancing Girl', Aesthetes and Decadents of the 1890's: Anthology of British Poetry and Prose, ed. Karl Beckson (Chicago: Academy Chicago Publishers, 1982), 2-3.

${ }^{49}$ Arthur Symons, 'To a Dancer' in Aesthetes and Decadents, 155.

${ }^{50}$ Arthur Symons, 'Prologue: In the Stalls' in Aesthetes and Decadents, 154.

${ }^{51}$ Linda K. Hughes, 'Women Poets and Contested Spaces in The Yellow Book', SEL Studies in English Literature 1500-1900, 44.4 (2004), 850.

${ }^{52}$ Custance, 'Peacocks', The Blue Bird (London: The Marlborough Press, 1905), 40. 